\title{
A Review on Bio-Based Catalysts (Immobilized Enzymes) Used for Biodiesel Production
}

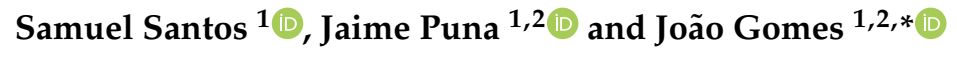 \\ 1 CERENA-Center for Natural Resources, Instituto Superior Técnico, Lisbon University, Av. Rovisco Pais, 1, \\ 1049-001 Lisboa, Portugal; samuelpsantos@tecnico.ulisboa.pt (S.S.); jpuna@deq.isel.ipl.pt (J.P.) \\ 2 Chemical Engineering Department, Instituto Superior de Engenharia de Lisboa, Lisbon Polytechnic, \\ R. Conselheiro Emídio Navarro, 1, 1959-007 Lisboa, Portugal \\ * Correspondence: jgomes@deq.isel.ipl.pt
}

Received: 14 May 2020; Accepted: 9 June 2020; Published: 11 June 2020

\begin{abstract}
The continuous increase of the world's population results in an increased demand for energy drastically from the industrial and domestic sectors as well. Moreover, the current public awareness regarding issues such as pollution and overuse of petroleum fuel has resulted in the development of research approaches concerning alternative renewable energy sources. Amongst the various options for renewable energies used in transportation systems, biodiesel is considered the most suitable replacement for fossil-based diesel. In what concerns the industrial application for biodiesel production, homogeneous catalysts such as sodium hydroxide, potassium hydroxide, sulfuric acid, and hydrochloric acid are usually selected, but their removal after reaction could prove to be rather complex and sometimes polluting, resulting in increases on the production costs. Therefore, there is an open field for research on new catalysts regarding biodiesel production, which can comprise heterogeneous catalysts. Apart from that, there are other alternatives to these chemical catalysts. Enzymatic catalysts have also been used in biodiesel production by employing lipases as biocatalysts. For economic reasons, and reusability and recycling, the lipases urged to be immobilized on suitable supports, thus the concept of heterogeneous biocatalysis comes in existence. Just like other heterogeneous catalytic materials, this one also presents similar issues with inefficiency and mass-transfer limitations. A solution to overcome the said limitations can be to consider the use of nanostructures to support enzyme immobilization, thus obtaining new heterogeneous biocatalysts. This review mainly focuses on the application of enzymatic catalysts as well as nano(bio)catalysts in transesterification reaction and their multiple methods of synthesis.
\end{abstract}

Keywords: biodiesel production; transesterification; enzymatic catalysis; immobilization of enzymes; biocatalyst; nano(bio)catalyst

\section{Introduction}

Biocatalysts based on enzymes have been investigated for decades due to their catalytic power, their high degree of specificity, and stereoselectivity [1-3]. These properties allow enzymes to catalyze reactions undergoing in milder conditions, such as low temperature and pressure, turning them into interesting candidates for several industrial applications [1,4].

Considering biodiesel production using biocatalysts, enzymatic transesterification using lipases has recently got the attention of researchers. Lipases are triacylglycerol acylhydrolases that exist on animals, plant, and microorganisms [5,6].

According to the literature, lipases used in the production of biodiesel come from microorganisms, such as Aspergillus niger [7], Burkholderia cepacian ([8,9], Candida Antarctica [10-12], Candida rugose [13], Mucor mihei [14,15], Pseudomonas cepacian [16], Pseudomonas fluorescens [17,18], Rhizopus oryzae [19], 
Rhizomucor miehei [20,21], and Thermomyces lanuginosus [22,23], to name a few. It is known that, in nature, they catalyze the hydrolysis of triglycerides to glycerol and free fatty acids as being present in the oil-water interface. Furthermore, lipases can also serve as a catalyst in esterification and transesterification reactions [24].

Usually, lipases can achieve fatty acid alkyl esters (FAAE) conversion yields of over $90 \%$ after long reaction times (sometimes over $70 \mathrm{~h}$ ), while reaction temperatures can range from $30{ }^{\circ} \mathrm{C}$ to $50{ }^{\circ} \mathrm{C}[25]$.

In comparison with the transesterification of triglycerides using chemical catalysts, biodiesel production by lipase-catalysis offers some benefits, such as ease of product separation (and consequently, ease of glycerol separation), wastewater treatment requirement is reduced to a minimum and the complete lack of side reactions [26-28].

Another major benefit lays in the possibility to process raw materials such as waste cooking oils (WCO), thus having high free fatty acid (FFA) content. As conventional homogenous alkaline catalyzed transesterification cannot achieve acceptable yields of FAAE due to the saponification reaction, the use of lipases to transform WCO into biodiesel may be a viable alternative by being able to process FFA and FAAE, thus offering a green route for biodiesel production at mild reaction conditions $[25,28,29]$.

Still, there are some technical drawbacks with using biocatalysts in biodiesel production, such as slower reaction rate than the alkaline catalyst (resulting in lower process productivity) and the risk of enzyme inactivation due to its sensitivity to methanol concentration [30].

Nevertheless, lipases used in biodiesel production have to be non-stereospecific, so that all compounds of different molecular lengths, such as tri-, di-, monoglycerides, and FFA of different lengths, can be efficiently converted into FAAE [28,31-33].

\section{Immobilization of Lipases}

Nevertheless, these biocatalysts present some disadvantages. The use of free enzymes as catalysts is not economically viable as these substances are not always as stable as required under operational conditions and restricted to one-time usage. Moreover, enzyme separation from the reaction mixture is very complicated, making catalyst recycling very much impossible $[4,34,35]$. This is the main limitation of the large-scale application of enzymatic methods [27].

One way to overcome these drawbacks consists in the enzyme immobilization onto supports. The immobilization of enzymes in solid carriers results in increasing chemical and thermal chemical stability, as well, and, also, contributes to protect the enzyme molecules from denaturation [32]. Furthermore, immobilized enzymes can be described as being enclosed physically or located in a specific space while retaining its catalytic properties, and with the advantage of possibly being used repeatedly and continuously [36,37]. However, there are some concerns with lipase immobilization. One is the possibility of enzyme shape change within the support matrix or getting detached, resulting in a drop in its catalytic activity. Another concern is the support materials being limited by their cost [38]. Thus far, some immobilization techniques were already developed, such as physical adsorption, entrapment, covalent attachment, and cross-linking (Figure 1) [1,39,40], which are the most used currently. 


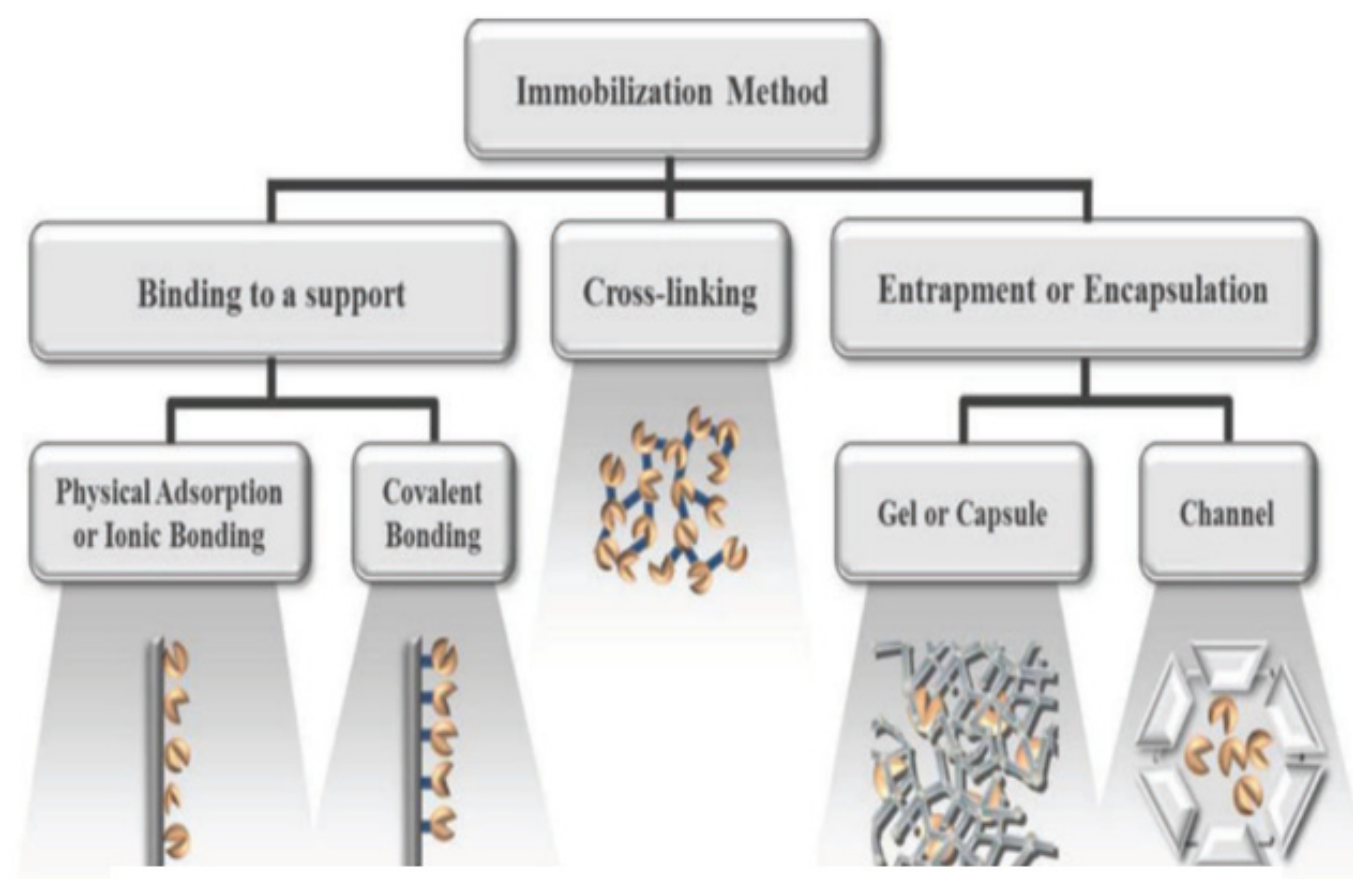

Figure 1. Overview of the different enzyme immobilization strategies [41].

\section{Physical Adsorption}

The physical adsorption process of a protein onto a supporting material is regarded as very simple and one the most used method. In adsorption, the enzyme is immobilized through the existence of low energy bonds, e.g., van der Waals or hydrophobic interactions, hydrogen bonds, or ionic bonds within the exterior surface of the supporting material $[42,43]$.

De Paola et al. [44] performed factor analysis concerning the enzymatic transesterification of waste oil aiming at biodiesel production. The chosen biocatalyst was a lipase extracted from Rhizomocur miehei immobilized on a macroporous ion-exchange hydrophilic resin having an irregular shape, dimensions from 0.02 and $0.06 \mathrm{~cm}, 0.4 \mathrm{~g} / \mathrm{cm}^{3}$ in terms of bulk density of, and a porosity of $0.53 \pm 0.02$. In this case, the developed model predictions were in good agreement with experimental data, with yields of $90 \%$ for $8 \mathrm{~h}$ of reaction [44].

Yagiz et al. [45] studied hydrotalcite and four other types of zeolites (13-X, 5A, FM-8, and AW-300) as immobilization material for lipases by physical adsorption. The absorbed amount of lipase on hydrotalcite reached its highest at $\mathrm{pH} 8.5$ and $4{ }^{\circ} \mathrm{C}$. The obtained immobilized lipase was found to retain, after the seventh reuse cycle, $36 \%$ of its initial activity at $45{ }^{\circ} \mathrm{C}$ and $14 \%$ at $55{ }^{\circ} \mathrm{C}$ for the transesterification of WCO. Comparing the obtained results, for a reaction time of $105 \mathrm{~h}$, the free lipase achieved a yield of $95 \%$, and the immobilized lipase in hydrotalcite, a yield of $92.8 \%$. However, considering the amount of lipase in the reaction, the immobilized lipase exhibited higher activity. The main reason for this could be that hydrotalcite; itself, is already an active site for transesterification reaction, and, thus, it has been used as a solid base heterogeneous catalyst in the transesterification reaction of edible oils. For the other types of support, the transesterification reaction showed no conversion of triglycerides to FAAE [45].

Shah et al. [46] produced biodiesel performing the alcoholysis of Jatropha curcas (non-edible) oil using biocatalysts. The best yield achieved was $98 \%(w / w)$ for Pseudomonas cepacia immobilized by adsorption on celite, at $50^{\circ} \mathrm{C}$ with the presence of $4-5 \%(w / w)$ water in $8 \mathrm{~h}$ of reaction. They also assessed that this catalyst could be recycled, at least, four times without any significant loss of activity [46].

Katiyar and Ali [47] studied the preparation of molecular sieve MCM-41 as effective support concerning the immobilization of Candida rugosa lipase using the physical adsorption technique. They observed a maximum point for lipase immobilization $(250 \mathrm{mg} / \mathrm{g})$ on this support at $\mathrm{pH} 6$ and the 
resulting immobilized lipase was used as biocatalysts for the transesterification of the cottonseed oil using methanol. Further optimization of all the reaction conditions $(\mathrm{pH}$, temperature, and methanol/oil molar ratio), resulted in a maximum yield of FAME (98.3\%) [47].

Nevertheless, enzyme leaching is a real problem, in what concerns physical adsorption, as this greatly limits the use of the immobilized enzyme for different reaction conditions $[48,49]$. One solution for this problem might be employing entrapment to restrict the enzyme inside the support framework [50,51].

\section{Entrapment}

Entrapment is another physical immobilization method that refers to the capture of a lipase typically in a polymeric network such as an organic polymer or microcapsules of polymers allowing that the substrate and other products could pass through but still retaining the lipase. Usually, lipase entrapment is performed in situ, e.g., the lipase is placed into the monomeric phase solution, and as polymerization reaction develops, results in its entrapment $[18,42,43]$. Compared with physical adsorption, lipase immobilization by entrapment is much more stable and protects the enzyme from the surrounding environment (hydrophobic solvents, mechanical sheer, and gas bubbles) [52].

Moreno-Pirajàn and Giraldo [53] studied the enzymatic transesterification of palm oil both with methanol and ethanol. The lipase Candida rugosa was investigated in immobilized form entrapped within the support of activated carbon. This lipase, of the four that were tested, resulted in the highest yield of FAAE. Under optimal reaction conditions, FAME, and FAEE formation, after $1 \mathrm{~h}$ of reaction, was of 70 and $85 \%$ mol, respectively [53].

Noureddini et al. [54] studied the transesterification of soybean oil with methanol and ethanol using enzymes. They tested nine lipases and found that a lipase from Pseudomonas cepacian resulted in the highest yield of FAAE. This lipase was thus investigated in terms of its immobilization within a chemically inert and hydrophobic sol-gel support. Under optimal reaction conditions, FAME and FAEE yield, after $1 \mathrm{~h}$ of reaction, were 67 and $65 \%$ mol, respectively [54].

Kuan et al. [55] entrapped lipase from Pseudomonas cepacian in polyallylamine-mediated biometric silica. This biocatalyst was applied to the obtention of biodiesel with soybean oil and WCO as feedstock. For WCO transesterification, the optimal conditions were found to be $43.3^{\circ} \mathrm{C}$, substrate molar ratio of $5: 1$ and $38 \%(w / w) n$-hexane. The experimentally obtained conversion was $68 \%$, while the predicted conversion was $67 \%$ [55].

Hsu et al. [56] investigated the lipase-catalyzed synthesis of alkyl esterified from tallow and grease using Pseudomonas cepacian lipase immobilized within a phyllosilicate sol-gel matrix. This lipase effectively converted the raw materials into ethyl esters by more than $95 \%$ when ethanol is used. The matrix-immobilized lipase was also recovered easily and could be reused for, at least, five times without losing any catalytic activity [56].

Unlike covalent bonding, a relatively simple procedure is followed, while, at the same time, the immobilized lipase can maintain its catalytic activity and stability also [57].

\section{Covalent Bonding}

Lipase immobilization obtained by covalent bonding to solid support consists of an irreversible bonding of the lipase to the support matrix [27]. This bond consists of a chemical reaction between the residue of active amino acid in the exterior of the active catalytic site of the lipase (usually thiol and amine groups) towards the active groups of the support matrix [58,59]. This method results in strong interactions between the lipase and the support, making enzyme leaching to the reaction moiety during the catalytic process very rare, as the activity and stability of the immobilized enzyme are directly related to the main characteristics of the support itself (pore size, chemical stability, and binding affinity to the enzyme) $[27,39,43]$. Multipoint covalent bonding seems to be the most efficient immobilization technique when compared to other methods in terms of thermal and operational lipase stability [60]. Tang et al. [61] assessed the immobilization of lipase from Candida cylindracea performed by covalent 
bonding with alkaline Ca-bentonite, modified with glutamic acid. The immobilized lipase exhibited a considerably higher catalytic activity. At $50{ }^{\circ} \mathrm{C}$, free lipase only retained $6 \%$ of its initial activity after $6 \mathrm{~h}$ of reaction. The Glu-Ca-Bent-lipase manages to retain $50 \%$ of its activity after $8 \mathrm{~h}$. The prepared biocatalyst for biodiesel production showed an improvement in achieving a transesterification reaction conversion of $99 \%$ when free lipase only achieved $52.8 \%$. Reusability wise, the said biocatalyst kept the reaction conversion at $56.2 \%$ after being reused five times, while the free lipase showed inactivity upon 2 uses [61].

Rodrigues et al. [62] evaluated the feasibility of biodiesel production by transesterification of Jatropha oil using methanol, catalyzed by non-commercial sn-1,3-regioselective lipases. Heterologous Rhizopus oryzae lipase (rROL) was immobilized by covalent bonding on different supports and was, then, tested. Transesterification reaction was tested at $30^{\circ} \mathrm{C}$, after seven stepwise methanol additions. All tested biocatalysts exhibited an average FAME conversion of $51-65 \%$ after $4 \mathrm{~h}$ of reaction [62].

Yücel [63] immobilized by covalent bonding microbial lipase form Thermomynces lanuginosus onto olive pomace. This support was then used to obtain biodiesel from pomace oil using methanol. Considering the optimized conditions, the maximum biodiesel yield was found to be $93 \%$ at $25{ }^{\circ} \mathrm{C}$ for a $24 \mathrm{~h}$ reaction. The immobilized enzyme maintained its activity during 10 repeated batch reactions [63].

Mendes et al. [60] immobilized microbial lipases from Thermomynces lanuginosus and Pseudomonas fluorescens by multipoint covalent bonding on Toyopearl AF-amino-650M resin and the obtained most active and thermal stable biocatalyst was used to catalyze the transesterification reaction of babassu and palm oils using ethanol. Comparing to the free lipase, Thermomynces lanuginosus immobilized biocatalyst presented the highest hydrolytic activity and thermal stability as well, being 27 to 31 times more stable. The highest conversion to biodiesel was found in the transesterification of palm oil catalyzed by both Thermomynces lanuginosus and Pseudomonas fluorescens biocatalysts, with transesterification yield exceeding 93.5\% [60].

\section{Cross-Linking}

The cross-linking technique is the basis to obtain the immobilization of lipase, which comprises the process to immobilize the enzyme through the formation of intermolecular cross-linkages using a cross-linker. Usually, cross-linkers are bi- or multi-functional reagents such as glutaraldehyde, bisdiazobenzidine, etc. Generally, this immobilization technique is support free and involves the aggregation of enzymes between themselves to obtain a 3-dimensional structure. This process starts with the precipitation of the enzyme aggregate using acetone. Then, the obtained aggregates are cross-linked by using a cross-linker so that to obtain a more robust structure $[35,64,65]$. Cross-linking can also be regarded as an improvement to covalent bonding, as the enzyme can be cross-linked to the support through the cross-linker. The procedure usually includes a previous step involving the immobilization on an ion exchange resin, followed by treatment with a buffered solution of cross-linker to form a Schiff base [43-49].

Abdulla and Ravindra [66] studied the immobilization of lipase from Burkholderia cepacian. In that study, the lipase was cross-linked with glutaraldehyde followed by entrapment into a hybrid matrix consisting of equal proportions of alginate and $\kappa$-carrageenan. Then, this biocatalyst was applied to the transesterification reaction of Jatropha curcas L. oil. For optimal conditions, a total conversion of fatty acid ethyl esters could be achieved. The immobilized lipase was found to be stable and able to retain $73 \%$ of the relative transesterification activity after 6 reuse cycles [66].

Dizge and Keskinler [67] developed a novel immobilization method of lipase from Termomynces lanuginosus within hydrophilic polyurethane foams, using polygluturaldehyde as a cross-linking agent. The immobilized lipase was used as a biocatalyst to produce biodiesel from canola oil and methanol and the effects of enzyme loading, alcohol/oil molar ratio, water concentration, and temperature in the transesterification reaction were studied. The maximum FAME yield achieved was $90 \%$, and it was found that enzymatic activity remained after 10 batches. The immobilized lipase exhibited stability and only lost little activity when subjected to repeated uses [67]. 
Kumari et al. [68] investigated the use of immobilizing lipase from Pseudomonas cepacian as a catalyst in the transesterification reaction of Madhuca indica oil. The best results were obtained when the cross-linked enzyme aggregates (CLEA) of the studied lipase are used. While free lipase powder could achieve a conversion yield of $98 \%$ in $6 \mathrm{~h}$ of reaction, after process optimization, CLEA of Pseudomonas cepacian gave a conversion of $92 \%$ in $2.5 \mathrm{~h}$ of reaction. Both methods used around the same amount of lipase [68].

Han and Kim [69] explored the methanol tolerant lipase M37 from Photobacterium lipolyticum and its immobilization by the cross-linked enzyme aggregate (CLEA) method. The cross-linked lipase can produce biodiesel from olive oil and alcohols such as methanol and ethanol. Regarding its physical stability and reusability, the cross-linked lipase can eventually be used as a catalyst for organic synthesis, including the biodiesel production reaction [69].

A summary of examples for lipase immobilization techniques is presented below in the form of a table (Table 1). For every example of biodiesel production using an immobilized lipase as biocatalyst, the respective name, technique for immobilization, lipidic feedstock, reaction parameters, and FAAE yields are displayed.

Table 1. Summary of examples of lipase immobilization techniques used in biodiesel production.

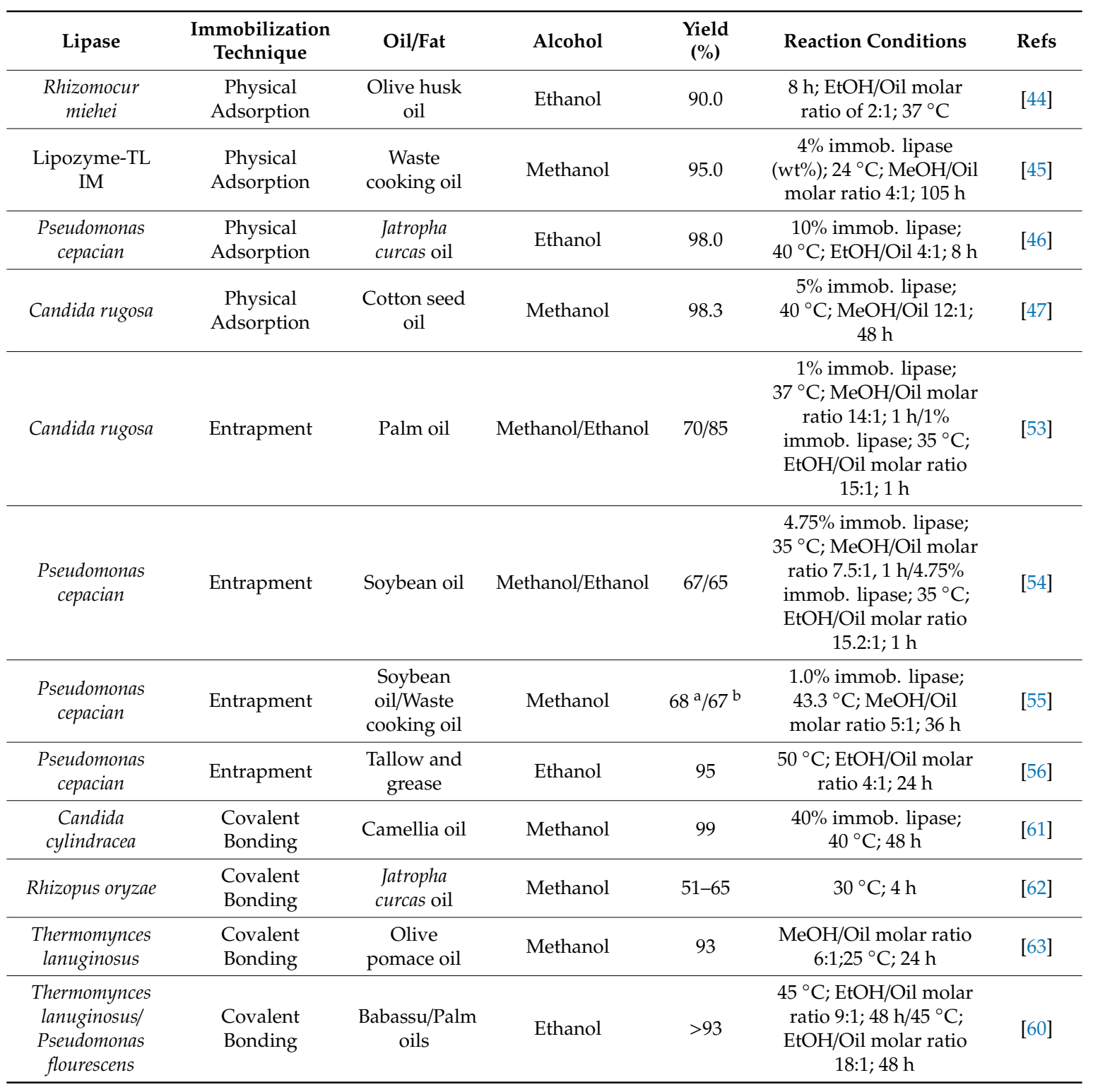


Table 1. Cont.

\begin{tabular}{|c|c|c|c|c|c|c|}
\hline Lipase & $\begin{array}{l}\text { Immobilization } \\
\text { Technique }\end{array}$ & Oil/Fat & Alcohol & $\begin{array}{c}\text { Yield } \\
(\%)\end{array}$ & Reaction Conditions & Refs \\
\hline $\begin{array}{l}\text { Burkholderia } \\
\text { cepacian }\end{array}$ & Cross-linking & $\begin{array}{l}\text { Jatropha } \\
\text { curcas oil }\end{array}$ & Ethanol & 100 & $\begin{array}{l}52.5 \% \text { immob. Lipase; } \\
35^{\circ} \mathrm{C} ; \mathrm{EtOH} / \mathrm{Oil} \mathrm{molar} \\
\text { ratio } 10: 1 ; 24 \mathrm{~h}\end{array}$ & [66] \\
\hline $\begin{array}{c}\text { Thermomynces } \\
\text { lanuginosus }\end{array}$ & Cross-linking & Canola oil & Methanol & 90 & $\begin{array}{c}40^{\circ} \mathrm{C} ; \mathrm{MeOH} / \mathrm{Oil} \text { molar } \\
\text { ratio } 6: 1 ; 24 \mathrm{~h}\end{array}$ & [67] \\
\hline $\begin{array}{l}\text { Pseudomonas } \\
\text { cepacian }\end{array}$ & Cross-linking & $\begin{array}{l}\text { Madhuca } \\
\text { indica oil }\end{array}$ & Ethanol & 92 & $\begin{array}{l}10 \% \text { immob. lipase; } \\
40^{\circ} \mathrm{C} \text {; EtOH/Oil molar } \\
\text { ratio } 4: 1 ; 2.5 \mathrm{~h}\end{array}$ & [68] \\
\hline $\begin{array}{l}\text { Photobacterium } \\
\text { lipolyticum }\end{array}$ & Cross-linking & Olive oil & Methanol & 64 & $\begin{array}{c}40^{\circ} \mathrm{C} ; \mathrm{MeOH} / \mathrm{Oil} \text { molar } \\
\text { ratio } 4: 1 ; 12 \mathrm{~h}\end{array}$ & [69] \\
\hline
\end{tabular}

${ }^{a}$ Experimentally obtained conversion; ${ }^{b}$ Predicted conversion.

\section{Nano-Structures}

Conventional immobilized enzyme materials lay typically on the micron size range [69]. Recently, many researchers have been investigating the use of nanomaterials as support matrixes for enzymes, due to their intrinsic large surface-to-area-to-volume, thus allowing high enzyme loading and enhanced mass transfer [41]. Immobilization of lipase on functionalized nanomaterials such as nanoparticles, nanofibers, nanotubes, and nanocomposites, show a high potential of applications, particularly, in the use of nano-immobilized lipase in packed-bed reactors, thus resulting in multiple reuses and effective protection from enzyme denaturation occurring in biodiesel production [70,71].

\subsection{Nanoparticles}

Nanoparticles, both inorganic and organic, have been extensively studied recently as possible supports for enzyme immobilization [72,73]. Among nanoparticles, we could create two separate groups: magnetic and non-magnetic.

\subsubsection{Non-Magnetic}

Typically, non-magnetic supports comprise zirconia, silica, polystyrene, chitosan, and polylactic acid.

Regarding inorganic nanoparticles, silica is among the most used inorganic support materials for enzyme immobilization. Its characteristics such as high thermal and chemical resistance, good mechanical properties, low cost, non-toxicity, and good compatibility make this material suitable for several applications. Silica supports (Figure 2) show good adsorption properties mainly due to its high surface area and porosity, thus resulting in effective enzyme immobilization and minimal diffusion limitations [74-78].

Macario et al. [79] studied the immobilization of lipase from Rhizomucor miehei in porous inorganic silica, and its use as biocatalyst for the transesterification reaction of triolein using methanol for biodiesel production. This biocatalyst achieved a substrate conversion of $98 \%$, resulting in a biodiesel yield of $89 \%$ for $3 \mathrm{~h}$ of reaction, at $37^{\circ} \mathrm{C}$ and a methanol/oil molar ration of 6:1 [79].

Babaki et al. [80] evaluated the enzymatic production of biodiesel by methanolysis from canola oil. Mesoporous SBA-15 nanoparticles were synthesized, characterized, and functionalized by 3-glycidiloxypropyl trimethysilane. Lipases from Candida antarctica, Thermomynces lanuginosus, and Rhizomucor miehei were, then, covalently immobilized onto SBA-epoxy. This evaluation comprised thermal stability and the influence of methanol concentration on the catalytic activity. The immobilized lipases showed rather good operational stability, being able to retain most of their activity after several cycles of reaction [80].

Other types of inorganic nanoparticles are nanometals. These nanoparticles usually include metal oxides such as zirconia, titania, and alumina, and other metals like gold and silver (Figure 3). These supports exhibit high stability, mechanical resistance, and good adsorption capacity. Furthermore, 
these materials, subjected to various reaction conditions, are inert, thus facilitating its application as supports in the immobilization of various classes of enzymes [40,81].

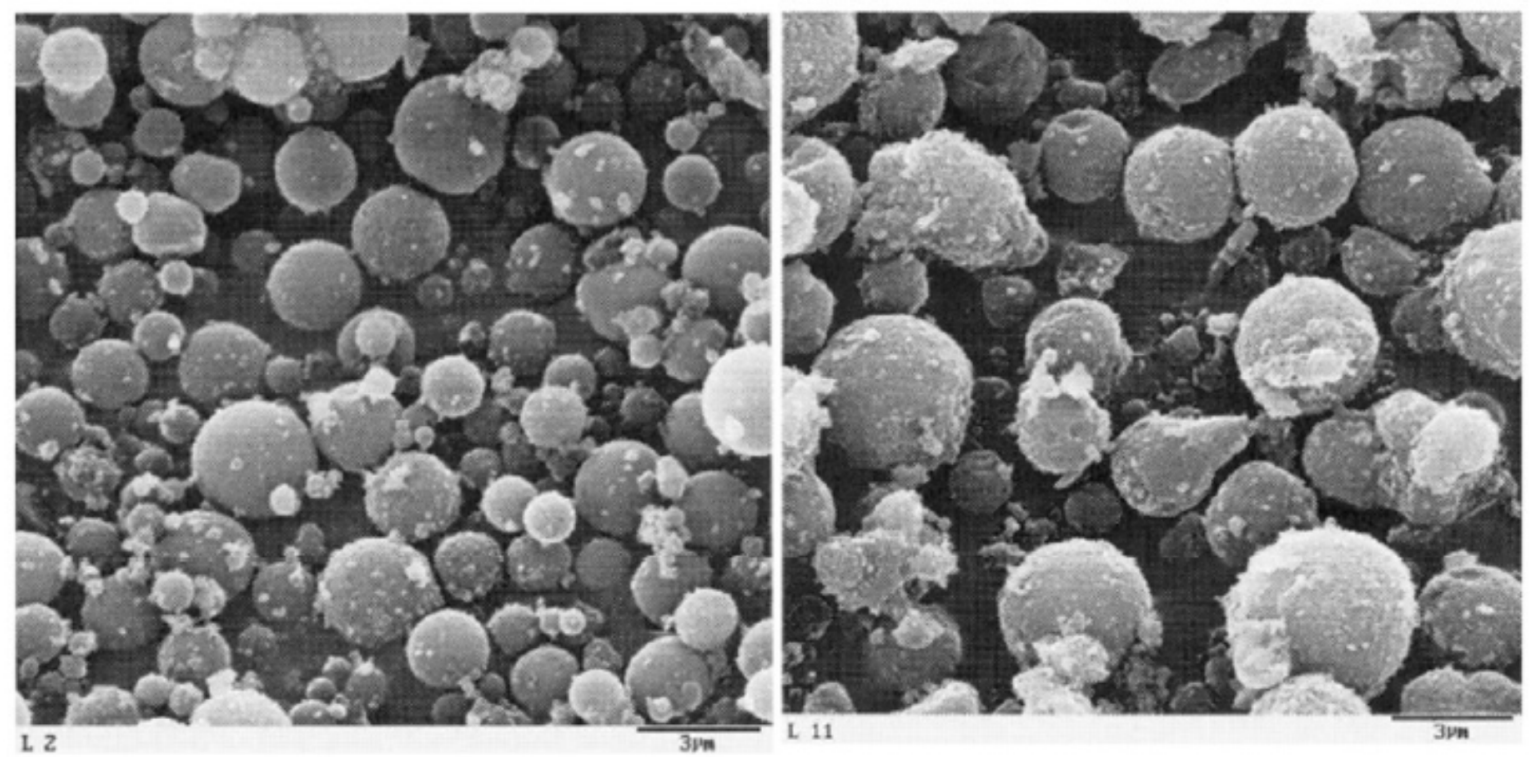

Figure 2. SEM photograph of silica nanoparticles [76].

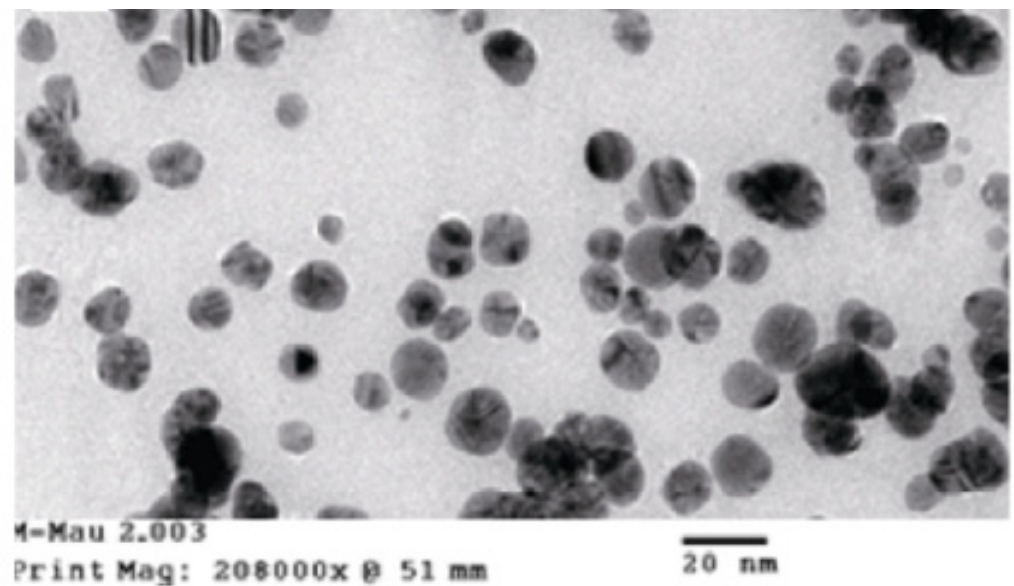

Figure 3. TEM image of silver nanoparticles [82].

Dumri and Anh [82] evaluated the immobilization of a novel lipase (EC3.1.1.3) onto polydopamine functionalized silver nanoparticles. Biodiesel production yield was assessed through gas chromatography and showed a result of $95 \%$ for the immobilized lipase at $40{ }^{\circ} \mathrm{C}$ for $6 \mathrm{~h}$ of reaction. In terms of reusability, the immobilized lipase was still active after 7 cycles and the conversion rate of soybean oil was only decreased by $27 \%$ [82].

Chen et al. [35] modified zirconia nanoparticles with a carboxylic acid having a long alkyl chain and proved that it can significantly enhance the activity of immobilized lipases. Comparing catalytic activity results for free Pseudomonas cepacian lipase and the immobilized lipase onto unmodified zirconia, the initial activity for the immobilized lipase is almost double the free lipase. If the best-modified zirconia is considered, then the initial activity becomes over sixteen times higher than free lipase [35].

Organic nanoparticles, such as chitosan, can be divided into two different classes: synthetic materials (chemical polymers) and renewable materials obtained from natural sources (biopolymers) [40,83]. Chitosan (Figure 4) is a biopolymer with vast potential as enzyme immobilization support [84]. Its nanoparticles possess bioactivity that is harmless for humans and presents outstanding physical-chemical, antimicrobial, and biological properties, that makes them viable for several 
applications, ranging from tissue engineering, pharmaceutical, and food packaging to biosensing, wastewater treatment, and enzyme immobilization [85].

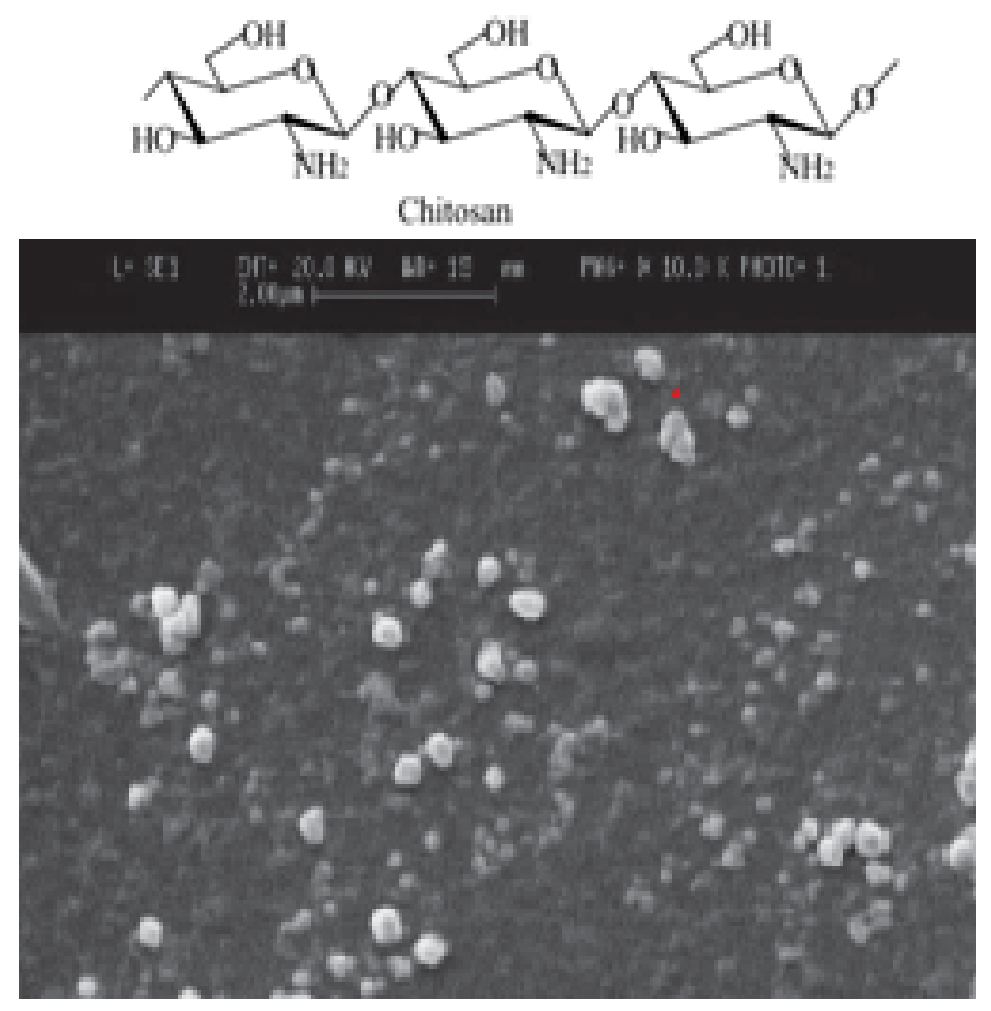

Figure 4. Structure of chitosan and SEM of chitosan nanoparticles $[84,85]$.

Besides that, the use of chitosan can also be commercially interesting due to its low cost, being obtained from the shell of shellfish (mainly crabs, shrimps, lobsters, and krills) and wastes of seafood processing industry $[81,84]$.

Ghadi et al. [85] synthesized chitosan magnetic core-shell nanoparticles to use them as support for Burkholderia cepacian lipase immobilization on the transesterification reaction of soybean oil. The catalytic activity of the synthesized biocatalyst was compared to the use of free lipase. Results showed that there was some improvement of the biological activity of the enzyme while it was immobilized onto the support due to polymeric and hydrophilic properties of chitosan [85].

Xie and Wang [86] immobilized a lipase onto magnetic chitosan nanoparticles aiming to prepare a biocatalyst effective for the transesterification of soybean oil. This immobilized lipase reached a FAME conversion yield of $87 \%$ under the optimized conditions of methanol/oil molar ratio of 4:1 with a three-step addition of methanol at $35^{\circ} \mathrm{C}$ for $30 \mathrm{~h}$. Furthermore, the immobilized lipase could be reused up to four times without significant loss of catalytic activity [86].

Among nanoparticles, the non-magnetic supports for enzyme immobilization are well dispersed in the reaction solution. This creates a problem for the recovery of the biocatalysts to be reused, making it difficult to separate from the reaction mixture and requiring high-speed centrifugation [87].

\subsubsection{Magnetic}

A solution to overcome the problem of nanoparticle recovery is the attachment of the enzyme molecules to magnetic iron oxide nanoparticles (magnetite- $-\mathrm{Fe}_{3} \mathrm{O}_{4}$ ) and simple separation of the biocatalyst making use of an external magnetic field [36]. In lipase immobilization, magnetite is of great interest due to its low toxicity, biocompatibility, large surface area, the abundance of hydroxyl groups on their surface enabling effortless functionalization and strong covalent bonding of the enzyme (Figure 5) [88,89]. 


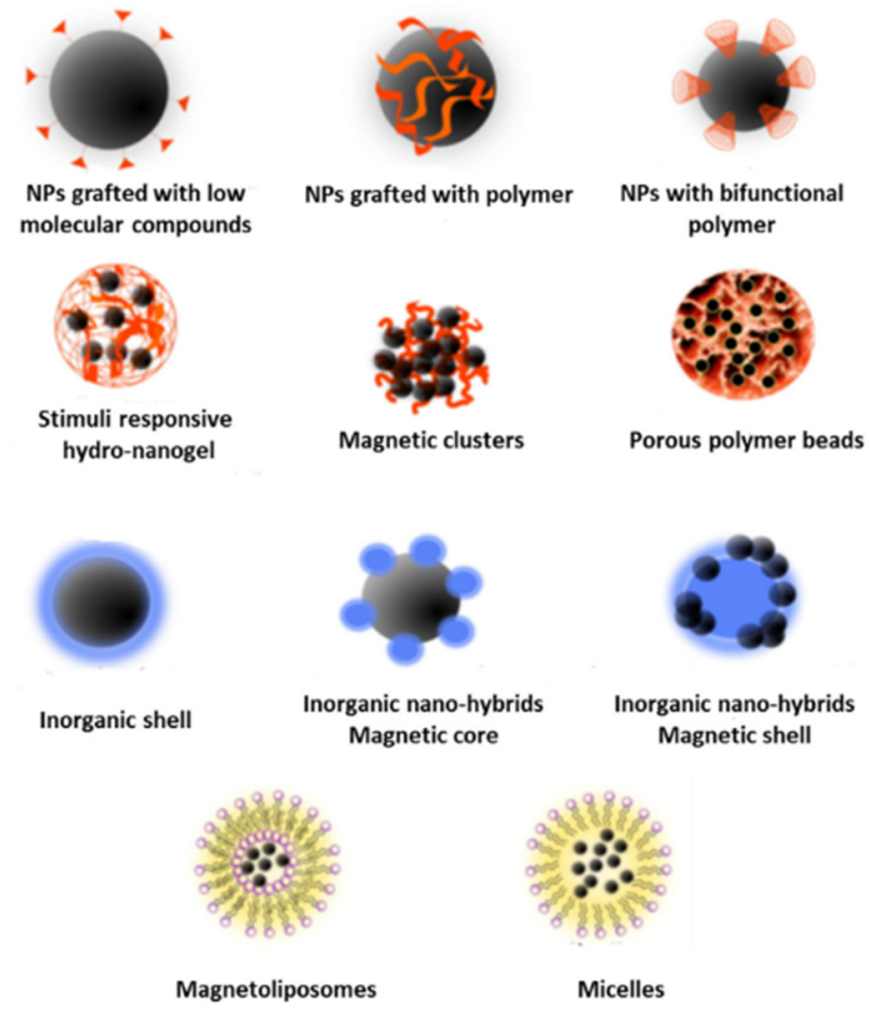

Figure 5. General types of magnetic nanoparticles arrangements with polymers, molecules, and inorganic nanoparticles [90].

However, bare magnetite always tends to aggregate due to the magnetic dipole-dipole attractions [90]. It was found that the functionalization of the magnetic nanoparticles of $\mathrm{Fe}_{3} \mathrm{O}_{4}$ can effectively improve its dispersity and chemical stability [91].

Lopez et al. [92] tested magnetic nanoparticles for the immobilization in two robust types of nanobiocatalysts. The first one was through covalent bonding of the lipase onto the magnetic nanoparticles' surface functionalized with amino groups and the second one was made by cross-linking aggregates of the enzyme (CLEA) between them and to the magnetic nanoparticles to produce magnetic CLEA. For this purpose, lipase B of Candida Antarctica was used. The nanobiocatalysts catalytic activity was evaluated in the transesterification reaction of olive oil at $40{ }^{\circ} \mathrm{C}$ with a 2-propanol/oil molar ratio of 6:1. In terms of catalytic activity, both nanobiocatalysts show similar results for the transesterification reaction with the magnetic CLEA having slightly higher numbers. Biodiesel conversion wise, the magnetic CLEA presents higher yields $(30.3 \%)$ when compared with immobilized lipase onto magnetic nanoparticles (20.5\%). In terms of stability, after 10 cycles of reuse, both nanobiocatalysts had their biodiesel conversion reduced to over 50\% [92].

Jambulingam et al. [93] produced biodiesel using a lipase immobilized onto functionalized magnetic nanoparticles. In this study, APTES ((3-aminopropyl) triethoxysilane) functionalized magnetic $\mathrm{Fe}_{3} \mathrm{O}_{4}$ nanoparticles were assessed for use in the transesterification of Aspergillus niger fungal lipid. The catalytic activity of the nanobiocatalyst allows for a biodiesel yield of $85.3 \%(w / w)$ at optimal reaction conditions. The nanobiocatalysts also showed catalytic activity after 5 cycles without any loss of performance [93].

\subsection{Carbon Nanotubes}

Because of their formidable mechanical properties, considerable large surface area, small size, unique morphology and chemical stability, carbon nanotubes, either being single-walled nanotubes 
(SWCNT) and multi-walled nanotubes (MWCNT) (Figure 6), are a promising and effective support for the immobilization of enzymes [71,94-96].

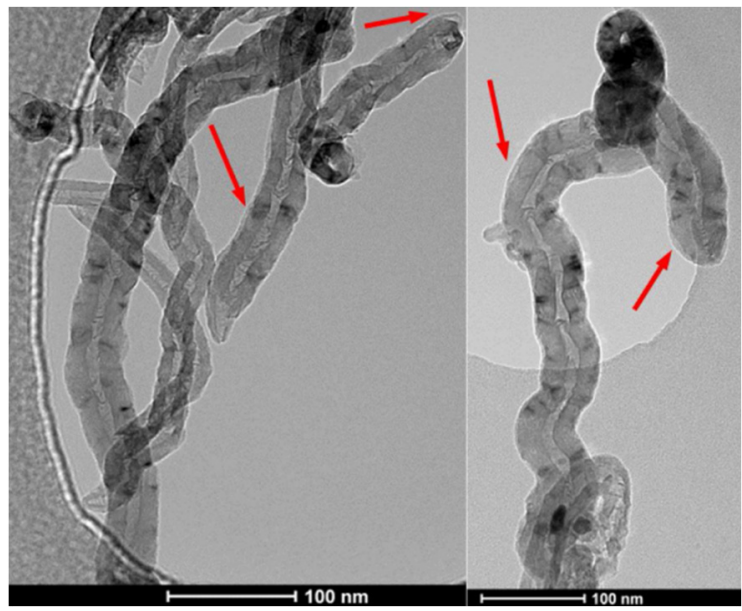

Figure 6. TEM images of multi-walled carbon nanotubes (MWCNTs) nanobiocatalysts. The red arrows indicated unevenly distributed coating by the lipase [96].

Nevertheless, the small size of the carbon nanotubes, one of its best properties is also one of its disadvantages, because the reduced size results that the recovery of the carbon nanotubes immobilized enzyme after the end of the reaction is a very difficult task. One solution for this problem is the combination of the carbon nanotubes with magnetic nanoparticles [97]. Despite magnetism solving the problem with recovery and reuse of the nanobiocatalysts, the active sites of the carbon nanotubes are not high enough and can only be introduced by functionalizing with dendrimer molecules $[28,98]$.

Bencze et al. [10] used single-walled carbon nanotubes as support for covalent immobilization of Candida Antarctica lipase B. The obtained nanobiocatalysts have a low diffusional limitation and were tested in batches in the ethanolysis of sunflower oil. The most efficient and stable biocatalyst achieved and conversion yield of $83.4 \%$ after $4 \mathrm{~h}$ of reaction at $35^{\circ} \mathrm{C}$, retaining over $90 \%$ of its original activity after 10 batches [10].

Fan et al. [99] grafted onto magnetic multi-walled carbon nanotubes (mMWCNT), a polyamidoamine (PAMAM) dendrimer, to combine magnetic properties with a large surface functionalized by amino groups. The obtained support was used in the immobilization of Rhizomucor miehei lipase. The authors also assessed the recovery which was quite high and the corresponding esterification activity of the immobilized enzyme was 27 times higher than the one of the free lipase. The said immobilized lipase was employed as biocatalyst in biodiesel production from waste cooking oil in a tert-butanol solvent system. Biodiesel conversion was as high as $94 \%$ under optimal conditions and the immobilized lipase could be recovered easily without showing a significant decrease in conversion rates after 10 cycles of reuse. Considering the aforementioned results, this immobilized lipase is a catalyst having high stability and exceptional reusability for biodiesel production [99].

\subsection{Nanofibers}

Some problems that certain nanoparticles and carbon nanotubes can suffer from is mass-transfer limitations and the difficulty in recycling due to their good dispersion properties [100]. A promising alternative support for enzyme immobilization able to overcome these problems is the use of nanofibers [71]. Nanofibers are already an extensively utilized support for lipase immobilization due to the essential functional groups (Figure 7) and uniform diameter they have, a very high surface area-to-volume ratios and ease of separation from the reaction mixture [100,101]. These materials are commonly prepared by self-assembly, electrospinning, template synthesis, and phase separation. Amongst these preparation methods, electrospinning is the most universal and highly effective one. 
Electrospun nanofibers present preferred dispersion and functional groups for lipase immobilization and almost infinite length [20,69].

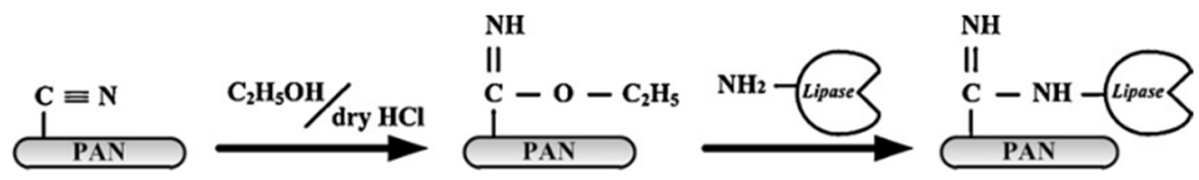

Figure 7. Schematic illustration of Pseudomonas cepacian lipase immobilized onto the polyacrylonitrile nanofibrous membrane by activating with the amidination reaction [102].

Li et al. [102] fabricated a nanofibrous membrane of polyacrylonitrile, by electrospinning, activated by an amidination reaction to immobilize Pseudomonas cepacian lipase. This immobilized lipase was then employed as biocatalyst for the transesterification reaction of soybean oil to biodiesel by adding methanol as solvent. Under optimal reaction conditions, the biodiesel conversion of soybean oil was $90 \%$ after reacting for $24 \mathrm{~h}$. In terms of reusability, the immobilized lipase retained still $91 \%$ of its initial catalytic activity after 10 cycles [102].

Sakai et al. [48] studied the production of butyl-biodiesel using electrospun polyacrylonitrile nanofibers with Pseudomonas cepacian immobilized via physical adsorption. $80 \%$ of conversion to butyl-biodiesel was achieved after $24 \mathrm{~h}$ of reaction, using a suspension of the biocatalyst at $2.4 \mathrm{mg} / \mathrm{mL}$ and an $n$-butanol/rapeseed oil molar ratio of $3: 1$ at $40{ }^{\circ} \mathrm{C}$. A further $24 \mathrm{~h}$ of reaction resulted in $94 \%$ of conversion. The immobilized lipase continued to be catalytically active for 27 days, within a $15 \%$ reduction in conversion yield [48].

\subsection{Nanocomposite}

Considering the unique characteristics of inorganic and organic nanoparticles aforesaid, researchers have investigated the possibility of maximizing the benefits of both by combining them. The resulting biocatalyst can exhibit properties that are not observed in their components [101]. An example of precursors for nanocomposites is magnetic nanoparticles (Figure 8).

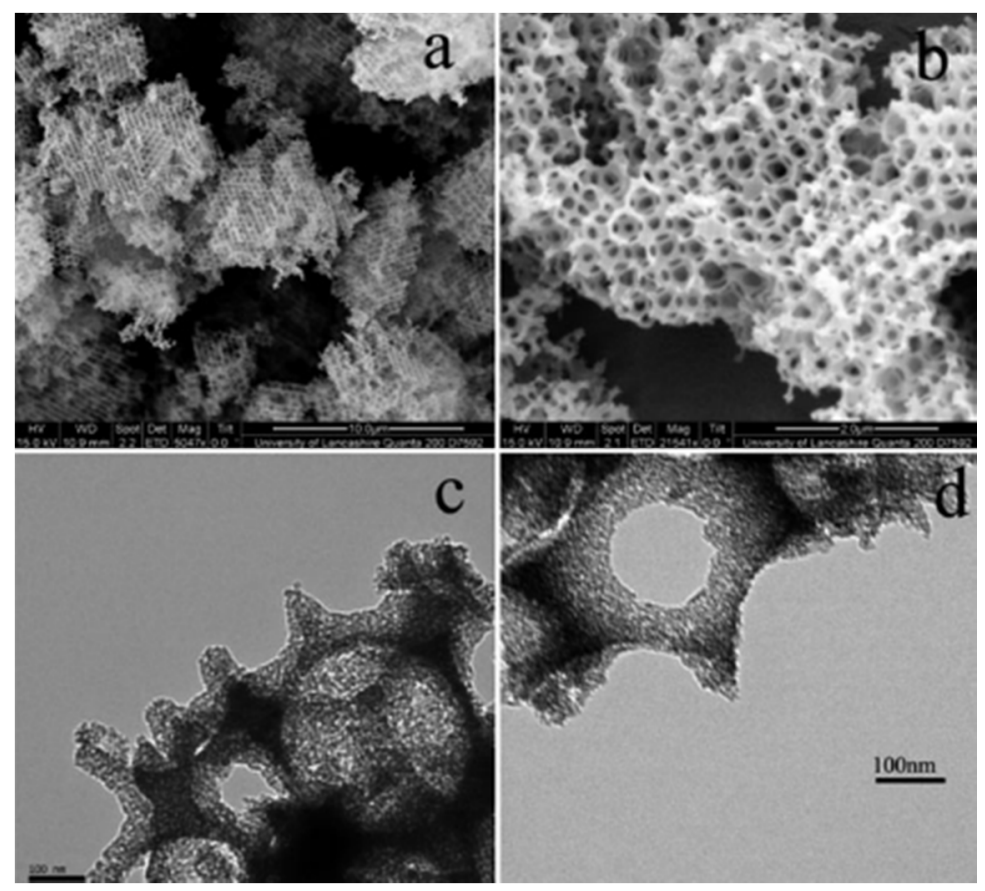

Figure 8. Electron micrographs of the magnetic composites: SEM (a,b); TEM (c,d) [103]. 
These nanomaterials are non-porous, and they could result in damages to the original nanoparticles due to the erosion of reacting agents [102]. To avoid this environmental reaction, the encapsulation or coating of nanoparticle with the desired organic/inorganic molecules represent an enhancement to their function as nanosupports, thus creating nanocomposites or hybrid materials [102-104]. This adds to the nanoparticle high versatility for surface modifications, becoming an ideal nanosupport for lipase immobilization [105].

Tran et al. [33] immobilized a lipase from Burkholderia sp. on magnetic nanoparticles to catalyze biodiesel synthesis. Core-shell nanoparticles were obtained by coating $\mathrm{Fe}_{3} \mathrm{O}_{4}$ core with silica shell. The nanoparticles were then treated with dimethyl octadecyl [3-(trimethoxysilyl) propyl] ammonium chloride. The immobilized lipase was applied as biocatalyst for the transesterification reaction of olive oil with methanol to produce FAME, attaining a FAME conversion of over $90 \%$ within $30 \mathrm{~h}$ of reaction, with $11 \mathrm{wt} \%$ of catalyst loading employed. The immobilized lipase was used for ten cycles without significant loss in its catalytic activity [33].

Mehrasbi et al. [106] covalently immobilized a lipase Candida antarctica on functionalized magnetic nanoparticles to catalyze the synthesis of biodiesel. Core-shell nanoparticles were, then, synthesized by coating $\mathrm{Fe}_{3} \mathrm{O}_{4}$ core with silica shell $\left(\mathrm{Fe}_{3} \mathrm{O}_{4} @ \mathrm{SiO}_{2}\right)$. These nanoparticles were functionalized with (3-glycidoxypropyl) trimethoxysilane (GPTMS) and utilized as a support for immobilization. When compared to the free lipase, the immobilized lipase presented higher thermal stability and, also, methanol tolerance. The immobilized lipase was then employed in the transesterification reaction of waste cooking oil using methanol. For optimum conditions, the biodiesel conversion yield was almost $100 \%$, with the immobilized lipase showing good reusability by retaining $100 \%$ of its prime catalytic activity after 6 cycles of reaction [106].

As it was done for the different lipase immobilization techniques and its application in biodiesel production, a summary of different nanomaterials capable of being used as support matrixes for lipase immobilization is presented below in the form of a table (Table 2). For every example of biodiesel production using these biocatalysts, the respective name, nano-support, lipidic feedstock, reaction parameters, and FAAE yields are displayed.

Table 2. Summary for nanobiocatalysts for biodiesel production.

\begin{tabular}{|c|c|c|c|c|c|c|}
\hline Lipase & Nano-Support & Oil/Fat & Alcohol & $\begin{array}{l}\text { Yield } \\
(\%)\end{array}$ & Reaction Conditions & Refs \\
\hline Rhizomocur mihei & $\begin{array}{l}\text { Porous inorganic } \\
\text { silica }\end{array}$ & Triolein & Methanol & 89 & $\begin{array}{c}10 \% \text { immob. lipase; } \\
37^{\circ} \mathrm{C} ; \text { MeOH/Oil molar } \\
\text { ratio 6:1;3 h }\end{array}$ & [79] \\
\hline $\begin{array}{c}\text { Candida } \\
\text { antarctical } \\
\text { Thermomynces } \\
\text { lanuginosus/ } \\
\text { Rhizomucor } \\
\text { miehei }\end{array}$ & $\begin{array}{l}\text { SBA-15 } \\
\text { functionalized by } \\
\text { 3-glycidiloxypropyl } \\
\text { trimethylsilane }\end{array}$ & Canola oil & Methanol & $24 / 33 / 34$ & $\begin{array}{c}3.8 \mathrm{wt} \% \text { immob. lipase; } \\
50^{\circ} \mathrm{C} ; \mathrm{MeOH} / \mathrm{Oil} \text { molar } \\
\text { ratio } 3: 1 ; 72 \mathrm{~h}\end{array}$ & [80] \\
\hline $\begin{array}{l}\text { Commercial } \\
\text { lipase } \\
\text { (EC3.1.1.3.) }\end{array}$ & $\begin{array}{c}\text { Polydopamine } \\
\text { functionalized silver } \\
\text { nanoparticles }\end{array}$ & Soybean oil & Methanol & 95 & $\begin{array}{l}40^{\circ} \mathrm{C} ; \mathrm{MeOH} / \mathrm{Oil} \text { molar } \\
\quad \text { ratio } 3: 1 ; 6 \mathrm{~h}\end{array}$ & {$[82]$} \\
\hline $\begin{array}{l}\text { Burkholderia } \\
\text { cepacian }\end{array}$ & $\begin{array}{c}\text { Chitosan magnetic } \\
\text { core-shell } \\
\text { nanoparticles }\end{array}$ & Soybean oil & Methanol & 18.66 & $\begin{array}{c}0.9 \% \text { immob. lipase; } \\
37^{\circ} \mathrm{C} ; \mathrm{MeOH} / \text { Oil molar } \\
\text { ratio 3:1;72 h }\end{array}$ & [85] \\
\hline Candida rugosa & $\begin{array}{l}\text { Magnetic chitosan } \\
\text { nanoparticles }\end{array}$ & Soybean oil & Methanol & 87 & $\begin{array}{c}35^{\circ} \mathrm{C} ; \mathrm{MeOH} / \text { Oil molar } \\
\text { ratio } 4: 1 ; 30 \mathrm{~h}\end{array}$ & [86] \\
\hline $\begin{array}{c}\text { Candida } \\
\text { antarctica }\end{array}$ & $\begin{array}{l}\text { Magnetic cross-linked } \\
\text { enzyme aggregates }\end{array}$ & Olive oil & 2-propanol & 30.3 & $\begin{array}{c}1 \mathrm{wt} \% \text { immob. lipase; } \\
40^{\circ} \mathrm{C} ; 2 \text { 2-Propanol/Oil } \\
\text { molar ratio } 6: 1\end{array}$ & [92] \\
\hline
\end{tabular}


Table 2. Cont.

\begin{tabular}{|c|c|c|c|c|c|c|}
\hline Lipase & Nano-Support & Oil/Fat & Alcohol & $\begin{array}{c}\text { Yield } \\
(\%)\end{array}$ & Reaction Conditions & Refs \\
\hline NA & $\begin{array}{l}\text { (3-aminopropyl) } \\
\text { triethoxysilane } \\
\text { functionalized } \\
\text { magnetic } \mathrm{Fe}_{3} \mathrm{O}_{4} \\
\text { nanoparticles }\end{array}$ & $\begin{array}{l}\text { Aspergillus } \\
\text { niger fungal } \\
\text { lipid }\end{array}$ & Methanol & 85.3 & $\begin{array}{l}6 \mathrm{wt} \% \text { immob. lipase; } \\
45^{\circ} \mathrm{C} ; \mathrm{MeOH} / \text { Oil molar } \\
\text { ratio } 4: 1 ; 4 \mathrm{~h}\end{array}$ & [93] \\
\hline $\begin{array}{l}\text { Candida } \\
\text { antarctica }\end{array}$ & $\begin{array}{l}\text { Single-walled carbon } \\
\text { nanotubes (SWCNTs) }\end{array}$ & $\begin{array}{l}\text { Sunflower } \\
\text { oil }\end{array}$ & Ethanol & 83.4 & $\begin{array}{c}15 \mathrm{wt} \% \text { immob. lipase; } \\
35^{\circ} \mathrm{C} ; 3.9 \mu \mathrm{L} \text { of ethanol; } \\
4 \mathrm{~h}\end{array}$ & [10] \\
\hline $\begin{array}{l}\text { Rhizomucor } \\
\text { miehei }\end{array}$ & $\begin{array}{l}\text { Polyamidoamine } \\
\text { grafted onto magnetic } \\
\text { multi-walled carbon } \\
\text { nanotubes } \\
\text { (mMWCNTs) }\end{array}$ & $\begin{array}{c}\text { Waste } \\
\text { cooking oil }\end{array}$ & tert-butanol & 94 & $\begin{array}{c}6 \mathrm{wt} \% \text { immob. lipase; } \\
50{ }^{\circ} \mathrm{C} ; 20 \mathrm{wt} \% \\
\text { tert-butanol; } 10 \mathrm{~h}\end{array}$ & [100] \\
\hline $\begin{array}{l}\text { Pseudomonas } \\
\text { cepacian }\end{array}$ & $\begin{array}{l}\text { Nanofibrous } \\
\text { membrane of } \\
\text { polyacrylate }\end{array}$ & Soybean oil & Methanol & 90 & $\begin{array}{l}0.35 \mathrm{wt} \% \text { immob. lipase; } \\
30{ }^{\circ} \mathrm{C} ; \mathrm{MeOH} \\
\text { concentration } 51 \mathrm{wt} \% \\
24 \mathrm{~h}\end{array}$ & [102] \\
\hline $\begin{array}{l}\text { Pseudomonas } \\
\text { cepacian }\end{array}$ & $\begin{array}{l}\text { Electrospun } \\
\text { polyacrylonitrile } \\
\text { nanofibers }\end{array}$ & Rapeseed oil & $n$-butanol & 94 & $\begin{array}{l}n \text {-butanol/Oil molar } \\
\text { ratio } 3: 1 ; 40{ }^{\circ} \mathrm{C} ; 48 \mathrm{~h}\end{array}$ & [103] \\
\hline Burkholderia sp. & $\begin{array}{l}\mathrm{Fe}_{3} \mathrm{O}_{4} \text { core coated } \\
\text { with silica shell and } \\
\text { treated with } \\
\text { [3-(trimethoxysilyl) } \\
\text { propyl]ammonium } \\
\text { chloride }\end{array}$ & Olive oil & Methanol & 90 & $\begin{array}{c}11 \mathrm{wt} \% \text { immob. lipase; } \\
40^{\circ} \mathrm{C} ; \mathrm{MeOH} / \text { Oil molar } \\
\text { ratio } 4: 1 ; 30 \mathrm{~h}\end{array}$ & [33] \\
\hline $\begin{array}{l}\text { Candida } \\
\text { antarctica }\end{array}$ & $\begin{array}{l}\mathrm{Fe}_{3} \mathrm{O}_{4} \text { core coated } \\
\text { with silica shell } \\
\text { functionalized with } \\
\text { (3-glycidoxypropyl) } \\
\text { trimethoxy silane) }\end{array}$ & $\begin{array}{c}\text { Waste } \\
\text { cooking oil }\end{array}$ & Methanol & 96 & $\begin{array}{c}70 \% \text { molecular sieve; } 4.5 \\
\text { wt } \% \text { immb. Lipase; } \\
\text { MeOH/Oil molar ratio } \\
\text { 3:1; } 50{ }^{\circ} \mathrm{C} ; 96 \mathrm{~h}\end{array}$ & [106] \\
\hline
\end{tabular}

\section{Conclusions}

Enzymatic catalysis has been used in biodiesel production by employing lipases as biocatalysts. But, for economic reasons and for reusability and recycling, the lipases urged to be immobilized on suitable supports, thus the concept of heterogeneous biocatalysis comes in existence.

Regarding lipase immobilization, different techniques were approached in this review. Comparing the two physical ones, physical adsorption, and entrapment, the latter appears to be the most suitable. The lipase immobilization within a support framework, instead of just being adsorbed on the surface of the support, prevents its leaching into the reaction mixture, protecting it from the surrounding environment. For the other two techniques, covalent bonding is the most efficient immobilization technique, being even the most efficient of them all, and it can also be improved by cross-linking because the enzyme can be cross-linked to the support through the cross-linker.

Just like other heterogeneous catalytic materials, this one also presents similar issues with inefficiency and mass-transfer limitations. A solution to overcome the said limitations could be the use of nano-structured supports for enzyme immobilization thus resulting in new heterogeneous biocatalysts with improved properties and enhanced behavior. Considering the use of nanomaterials as support matrixes for enzymes, nanoparticles have been extensively studied and can be separated into two groups: magnetic and non-magnetic. Non-magnetic nanoparticles present very good support properties, and, just like single-walled carbon nanotubes (SWCNTs) and also multi-walled carbon nanotubes (MWCNTs), they are an effective support for enzyme immobilization but its small size and good dispersion in the reaction mixture makes their recovery after the end of the reaction a very difficult task. One possible solution to overcome the problem of recovery are functionalized magnetic nanoparticles of magnetite $\left(\mathrm{Fe}_{3} \mathrm{O}_{4}\right)$. These materials, whether as a support matrix for enzyme 
immobilization or combined with other nanomaterials, bring improvement in enzyme recovery by allowing simple separation of the biocatalyst with the use of an external magnetic field. The resulting materials of said combination are hybrid nanomaterials called nanocomposites. Together with nanofibers, nanocomposites are a promising alternative support for enzyme immobilization due to being able to overcome mass-transfer limitations and difficulty in recycling the biocatalyst.

Author Contributions: Conceptualization, J.G. and J.P.; investigation S.S.; writing-original draft preparation, S.S.; writing-review and editing, J.G. and J.P. All authors have read and agreed to the published version of the manuscript.

Funding: This research received no external funding.

Conflicts of Interest: The authors declare no conflict of interest.

\section{References}

1. Bilal, M.; Zhao, Y.; Noreen, S.; Shah, S.Z.H.; Bharagava, R.N.; Iqbal, H.M.N. Modifying bio-catalytic properties of enzymes for efficient biocatalysis: A review from immobilization strategies viewpoint. Biocatal. Biotransform. 2019, 37, 159-182. [CrossRef]

2. Carteret, C.; Jacoby, J.; Blin, J.L. Using factorial experimental design to optimize biocatalytic biodiesel production from Mucor Miehei Lipase immobilized onto ordered mesoporous materials. Microporous Mesoporous Mater. 2018, 268, 39-45. [CrossRef]

3. Pollard, D.J.; Woodley, J.M. Biocatalysis for Pharmaceutical Intermediates: The Future Is Now. Trends Biotechnol. 2007, 25, 66-73. [CrossRef]

4. Garcia-Galan, C.; Berenguer-Murcia, Á.; Fernandez-Lafuente, R.; Rodrigues, R.C. Potential of different enzyme immobilization strategies to improve enzyme performance. Adv. Synth. Catal. 2011, 353, 2885-2904. [CrossRef]

5. Kakugawa, K.; Shobayashi, M.; Suzuki, O.; Miyakawa, T. Purification and characterization of a lipase from the glycolipid-producing yeast kurtzmanomyces sp. I-11. Biosci. Biotechnol. Biochem. 2002, 66, 978-985. [CrossRef] [PubMed]

6. Szczęsna Antczak, M.; Kubiak, A.; Antczak, T.; Bielecki, S. Enzymatic biodiesel synthesis-Key factors affecting efficiency of the process. Renew. Energy 2009, 34, 1185-1194. [CrossRef]

7. Hu, Y.; Dai, L.; Liu, D.; Du, W. Rationally designing hydrophobic UiO-66 support for the enhanced enzymatic performance of immobilized lipase. Green Chem. 2018, 20, 4500-4506. [CrossRef]

8. Liu, L.H.; Shih, Y.H.; Liu, W.L.; Lin, C.H.; Huang, H.Y. Enzyme Immobilized on Nanoporous Carbon Derived from Metal-Organic Framework: A New Support for Biodiesel Synthesis. ChemSusChem 2017, 10, 1364-1369. [CrossRef]

9. Shah, S.; Gupta, M.N. The effect of ultrasonic pre-treatment on the catalytic activity of lipases in aqueous and non-aqueous media. Chem. Cent. J. 2008, 2, 1-9. [CrossRef]

10. Bencze, L.C.; Bartha-Vári, J.H.; Katona, G.; Toşa, M.I.; Paizs, C.; Irimie, F.-D. Nanobioconjugates of Candida antarctica lipase B and single-walled carbon nanotubes in biodiesel production. Bioresour. Technol. 2016, 200, 853-860. [CrossRef]

11. Shimada, Y.; Watanabe, Y.; Sugihara, A.; Tominaga, Y. Enzymatic alcoholysis for biodiesel fuel production and application of the reaction to oil processing. J. Mol. Catal. B Enzymatic 2002, 17, 133-142. [CrossRef]

12. Wang, L.; Liu, X.; Jiang, Y.; Zhou, L.; Ma, L.; He, Y.; Gao, J. Biocatalytic pickering emulsions stabilized by lipase-immobilized carbon nanotubes for biodiesel production. Catalysts 2018, 8, 587. [CrossRef]

13. Rafiei, S.; Tangestaninejad, S.; Horcajada, P.; Moghadam, M.; Mirkhani, V.; Mohammadpoor-Baltork, I.; Kardanpour, R.; Zadehahmadi, F. Efficient biodiesel production using a lipase@ZIF-67 nanobioreactor. Chem. Eng. J. 2018, 334, 1233-1241. [CrossRef]

14. Gog, A.; Roman, M.; Toşa, M.; Paizs, C.; Irimie, F.D. Biodiesel production using enzymatic transesterification -Current state and perspectives. Renew. Energy 2012, 39, 10-16. [CrossRef]

15. Nelson, L.A.; Foglia, T.A.; Marmer, W.N. Lipase-catalyzed production of biodiesel. JAOCS J. Am. Oil Chem. Soc. 1996, 73, 1191-1195. [CrossRef] 
16. Li, S.-F.; Fan, Y.-H.; Hu, R.-F.; Wu, W.-T. Pseudomonas cepacia lipase immobilized onto the electrospun PAN nanofibrous membranes for biodiesel production from soybean oil. J. Mol. Catal. B Enzymatic 2011, 72, 40-45. [CrossRef]

17. Cubides-Roman, D.C.; Pérez, V.H.; de Castro, H.F.; Orrego, C.E.; Giraldo, O.H.; Silveira, E.G.; David, G.F. Ethyl esters (biodiesel) production by Pseudomonas fluorescens lipase immobilized on chitosan with magnetic properties in a bioreactor assisted by electromagnetic field. Fuel 2017, 196, 481-487. [CrossRef]

18. Zhao, X.; Qi, F.; Yuan, C.; Du, W.; Liu, D. Lipase-catalyzed process for biodiesel production: Enzyme immobilization, process simulation and optimization. Renew. Sust. Energy Rev. 2015, 44, 182-197. [CrossRef]

19. Jun, S.-H.; Lee, J.; Chan Kim, B.; Eun Lee, J.; Joo, J.; Park, H.; Ho Lee, J.; Lee, S.-M.; Lee, D.; Kim, S.; et al. Highly Efficient Enzyme Immobilization and Stabilization within Meso-Structured Onion-Like Silica for Biodiesel Production. Chem. Mater. 2012, 24, 924-929. [CrossRef]

20. Ahmed, F.E.; Lalia, B.S.; Hashaikeh, R. A review on electrospinning for membrane fabrication: Challenges and applications. Desalination 2015, 356, 15-30. [CrossRef]

21. Shieh, C.-J.; Liao, H.-F.; Lee, C.-C. Optimization of lipase-catalyzed biodiesel by response surface methodology. Bioresour. Technol. 2003, 88, 103-106. [CrossRef]

22. Du, W.; Xu, Y.-Y.; Liu, D.-H.; Li, Z.-B. Study on acyl migration in immobilized lipozyme TL-catalyzed transesterification of soybean oil for biodiesel production. J. Mol. Catal. B Enzymatic 2005, 37, 68-71. [CrossRef]

23. Xie, W.; Ma, N. Immobilized Lipase on Fe3O4 Nanoparticles as Biocatalyst for Biodiesel Production. Energy Fuels 2009, 23, 1347-1353. [CrossRef]

24. Aarthy, M.; Saravanan, P.; Gowthaman, M.K.; Rose, C.; Kamini, N.R. Enzymatic transesterification for production of biodiesel using yeast lipases: An overview. Chem. Eng. Res. Design 2014, 92, 1591-1601. [CrossRef]

25. Fjerbaek, L.; Christensen, K.V.; Norddahl, B. A review of the current state of biodiesel production using enzymatic transesterification. Biotechnol. Bioeng. 2009, 102, 1298-1315. [CrossRef]

26. Christopher, L.P.; Hemanathan, K.; Zambare, V.P. Enzymatic biodiesel: Challenges and opportunities. Appl. Energy 2014, 119, 497-520. [CrossRef]

27. Tan, T.; Lu, J.; Nie, K.; Deng, L.; Wang, F. Biodiesel production with immobilized lipase: A review. Biotechnol. Adv. 2010, 28, 628-634. [CrossRef]

28. Zhong, L.; Feng, Y.; Wang, G.; Wang, Z.; Bilal, M.; Lv, H.; Jia, S.; Cui, J. Production and use of immobilized lipases in/on nanomaterials: A review from the waste to biodiesel production. Int. J. Biol. Macromolecules 2020, 152, 207-222. [CrossRef]

29. Bajaj, A.; Lohan, P.; Jha, P.N.; Mehrotra, R. Biodiesel production through lipase catalyzed transesterification: An overview. J. Mol. Catal. B Enzymatic 2010, 62, 9-14. [CrossRef]

30. Sánchez-Bayo, A.; Morales, V.; Rodríguez, R.; Vicente, G.; Bautista, L.F. Biodiesel production (FAEEs) by heterogeneous combi-lipase biocatalysts using wet extracted lipids from microalgae. Catalysts 2019, 9, 296. [CrossRef]

31. Tacias-Pascacio, V.G.; Virgen-Ortíz, J.J.; Jiménez-Pérez, M.; Yates, M.; Torrestiana-Sanchez, B.; Rosales-Quintero, A.; Fernandez-Lafuente, R. Evaluation of different lipase biocatalysts in the production of biodiesel from used cooking oil: Critical role of the immobilization support. Fuel 2017, 200, 1-10. [CrossRef]

32. Tran, D.-T.; Chen, C.-L.; Chang, J.-S. Immobilization of Burkholderia sp. lipase on a ferric silica nanocomposite for biodiesel production. J. Biotechnol. 2012, 158, 112-119. [CrossRef] [PubMed]

33. Rodrigues, R.C.; Ortiz, C.; Berenguer-Murcia, Á.; Torres, R.; Fernández-Lafuente, R. Modifying enzyme activity and selectivity by immobilization. Chem. Soc. Rev. 2013, 42, 6290-6307. [CrossRef] [PubMed]

34. Jegannathan, K.R.; Abang, S.; Poncelet, D.; Chan, E.S.; Ravindra, P. Production of Biodiesel Using Immobilized Lipase-A critical Review. Crit. Rev.Biotechnol. 2008, 28, 253-264. [CrossRef]

35. Zhang, Y.; Ge, J.; Liu, Z. Enhanced Activity of Immobilized or chemically Modified Enzymes. ACS Catal. 2015, 5, 4503-4513. [CrossRef]

36. Dalla-Vecchia, R.; Nascimento, M.D.G.; Soldi, V. Aplicações sintéticas de lipases imobilizadas em polímeros. Química Nova 2004, 27, 623-630. [CrossRef]

37. Amini, Z.; Ilham, Z.; Ong, H.C.; Mazaheri, H.; Chen, W.H. State of art and prospective of lipase-catalyzed transesterification reaction for biodiesel production. Energy Convers. Manag. 2017, 141, 339-353. [CrossRef] 
38. Ricardi, N.C.; de Menezes, E.W.; Valmir Benvenutti, E.; da Natividade Schöffer, J.; Hackenhaar, C.R.; Hertz, P.F.; Costa, T.M.H. Highly stable novel silica/chitosan support for $\beta$-galactosidase immobilization for application in dairy technology. Food Chem. 2018, 246, 343-350. [CrossRef] [PubMed]

39. Zdarta, J.; Meyer, A.S.; Jesionowski, T.; Pinelo, M. A general overview of support materials for enzyme immobilization: Characteristics, properties, practical utility. Catalysts 2018, 8, 92. [CrossRef]

40. Hwang, E.T.; Gu, M.B. Enzyme stabilization by nano/microsized hybrid materials. Eng. Life Sci. 2013, 13, 49-61. [CrossRef]

41. Brady, D.; Jordaan, J. Advances in enzyme immobilisation. Biotechnol. Lett. 2009, 31, 1639-1650. [CrossRef] [PubMed]

42. Villeneuve, P.; Muderhwa, J.M.; Graille, J.; Haas, M.J. Customizing lipases for biocatalysis: A survey of chemical, physical and molecular biological approaches. J. Mol. Catal. B Enzymatic 2000, 9, 113-148. [CrossRef]

43. De Paola, M.G.; Ricca, E.; Calabrò, V.; Curcio, S.; Iorio, G. Factor analysis of transesterification reaction of waste oil for biodiesel production. Bioresour. Technol. 2009, 100, 5126-5131. [CrossRef] [PubMed]

44. Yagiz, F.; Kazan, D.; Akin, A.N. Biodiesel production from waste oils by using lipase immobilized on hydrotalcite and zeolites. Chem. Eng. J. 2007, 134, 262-267. [CrossRef]

45. Shah, S.; Gupta, M.N. Lipase catalyzed preparation of biodiesel from Jatropha oil in a solvent free system. Process BioChem. 2007, 42, 409-414. [CrossRef]

46. Katiyar, M.; Ali, A. Immobilization of Candida rugosa lipase on MCM-41 for the transesterification of cotton seed oil. J. Oleo Sci. 2012, 61, 469-475. [CrossRef]

47. Hartmann, M.; Jung, D. Biocatalysis with enzymes immobilized on mesoporous hosts: The status quo and future trends. J. Mater. Chem. 2010, 20, 844-857. [CrossRef]

48. Li, S.-F.; Chen, J.-P.; Wu, W.-T. Electrospun polyacrylonitrile nanofibrous membranes for lipase immobilization. J. Mol. Catal. B Enzymatic 2007, 47, 117-124. [CrossRef]

49. Safaryan, S.M.; Yakovlev, A.V.; Pidko, E.A.; Vinogradov, A.V.; Vinogradov, V.V. Reversible sol-gel-sol medium for enzymatic optical biosensors. J. Mater. Chem. B 2017, 5, 85-91. [CrossRef]

50. Souza, R.L.; Faria, E.L.P.; Figueiredo, R.T.; Mettedi, S.; Santos, O.A.A.; Lima, A.S.; Soares, C.M.F. Protic ionic liquid applied to enhance the immobilization of lipase in sol-gel matrices. J. Therm. Anal. Calorim. 2017, 128, 833-840. [CrossRef]

51. Lalonde, J.; Margolin, A. Immobilization of Enzymes. In Enzyme Catalysis in Organic Synthesis: A Comprehensive Handbook; Drauz, K., Waldmann, H., Eds.; Wiley-VCH Verlag GmbH: Weinheim, Germany, 2002; pp. 163-184.

52. Moreno-Pirajàn, J.C.; Giraldo, L. Study of immobilized candida rugosa lipase for biodiesel fuel production from palm oil by flow microcalorimetry. Arab. J. Chem. 2011, 4, 55-62. [CrossRef]

53. Noureddini, H.; Gao, X.; Philkana, R.S. Immobilized Pseudomonas cepacia lipase for biodiesel fuel production from soybean oil. Bioresour. Technol. 2005, 96, 769-777. [CrossRef]

54. Kuan, I.C.; Lee, C.C.; Tsai, B.H.; Lee, S.L.; Lee, W.T.; Yu, C.Y. Optimizing the production of biodiesel using lipase entrapped in biomimetic silica. Energies 2013, 6, 2052-2064. [CrossRef]

55. Hsu, A.F.; Jones, K.; Marmer, W.N.; Foglia, T.A. Production of alkyl esters from tallow and grease using lipase immobilized in a phyllosilicate sol-gel. JAOCS J. Am. Oil Chem. Soc. 2001, 78, 585-588. [CrossRef]

56. Kennedy, J.F.; Melo, E.H.M.; Jumel, K. Immobilized enzyme and cells. Chem. Eng. Prog. 1990, 86, 81-89.

57. Brena, B.M.; Batista-Viera, F. Immobilization of Enzymes. In Immobilization of Enzymes and Cells; Guisan, J.M., Ed.; Humana Press: Totowa, NJ, USA, 2006; pp. 15-30.

58. Stoycheva, M.; Montero, G.; Toscano, L.; Valdez, B. The Immobilized Lipases in Biodiesel Product; Stoycheva, M., Montero, G., Eds.; InTech: London, UK, 2011; pp. 397-410.

59. Mateo, C.; Fernandes, B.; van Rantwijk, F.; Stolz, A.; Sheldon, R.A. Stabilisation of oxygen-labile nitrilases via co-aggregation with poly(ethyleneimine). J. Mol. Catal. B Enzymatic 2006, 38, 154-157. [CrossRef]

60. Mendes, A.A.; Giordano, R.C.; de LC Giordano, R.; de Castro, H.F. Immobilization and stabilization of microbial lipases by multipoint covalent attachment on aldehyde-resin affinity: Application of the biocatalysts in biodiesel synthesis. J. Mol. Catal. B Enzymatic 2011, 68, 109-115. [CrossRef]

61. Tang, A.; Zhang, Y.; Wei, T.; Wu, J.; Li, Q.; Liu, Y. Immobilization of Candida cylindracea Lipase by Covalent Attachment on Glu-Modified Bentonite. Appl. BioChem. Biotechnol. 2019, 187, 870-883. [CrossRef] [PubMed] 
62. Rodrigues, J.; Canet, A.; Rivera, I.; Osório, N.M.; Sandoval, G.; Valero, F.; Ferreira-Dias, S. Biodiesel production from crude Jatropha oil catalyzed by non-commercial immobilized heterologous Rhizopus oryzae and Carica papaya lipases. Bioresour. Technol. 2016, 213, 88-95. [CrossRef] [PubMed]

63. Yücel, Y. Biodiesel production from pomace oil by using lipase immobilized onto olive pomace. Bioresour. Technol. 2011, 102, 3977-3980. [CrossRef] [PubMed]

64. Murty, V.R.; Bhat, J.; Muniswaran, P.K.A. Hydrolysis of oils by using immobilized lipase enzyme: A review. Biotechnol. Bioprocess Eng. 2002, 7, 57-66. [CrossRef]

65. Yugen, W.; Jian, X.; Guanjsheng, L.; Youyuan, Y. Immobilization of lipase by ultrafiltration and cross-bonding onto the polysulfone membrane surface. Bioresour. Technol. 2008, 99, 2299-2303.

66. Abdulla, R.; Ravindra, P. Immobilized Burkholderia cepacia lipase for biodiesel production from crude Jatropha curcas L. oil. Biomass Bioenerg. 2013, 56, 8-13. [CrossRef]

67. Dizge, N.; Keskinler, B. Enzymatic production of biodiesel from canola oil using immobilized lipase. Biomass Bioenerg. 2008, 32, 1274-1278. [CrossRef]

68. Kumari, V.; Shah, S.; Gupta, M.N. Preparation of Biodiesel by Lipase-Catalyzed Transesterification of High Free Fatty Acid Containing Oil from Madhuca indica. Energy Fuels 2006, 21, 368-372. [CrossRef]

69. Han, J.Y.; Kim, H.K. Transesterification using the cross-linked enzyme aggregate of Photobacterium lipolyticum Lipase M37. J. Microbiol. Biotechnol. 2011, 21, 1159-1165. [CrossRef]

70. Ansari, S.A.; Husain, Q. Potential applications of enzymes immobilized on/in nano materials: A review. Biotechnol. Adv. 2012, 30, 512-523. [CrossRef]

71. Kim, K.H.; Lee, O.K.; Lee, E.Y. Nano-immobilized biocatalysts for biodiesel production from renewable and sustainable resources. Catalysts 2018, 8, 68.

72. Verma, M.L.; Puri, M.; Barrow, C.J. Recent trends in nanomaterials immobilised enzymes for biofuel production. Crit. Rev. Biotechnol. 2016, 36, 108-119. [CrossRef]

73. Jia, H.; Zhu, G.; Wang, P. Catalytic Behaviors of Enzymes Attached to Nanoparticles: The Effect of Particle Mobility. Biotechnol. BioEng. 2003, 84, 406-414. [CrossRef]

74. Kim, J.; Grate, J.W.; Wang, P. Nanostructures for enzyme stabilization. Chem. Eng. Sci. 2006, 61, 1017-1026. [CrossRef]

75. Adlercreutz, P. Immobilisation and application of lipases in organic media. Chem. Soc. Rev. 2013, 42, 6406-6436. [CrossRef]

76. Jesionowski, T. Preparation of colloidal silica from sodium metasilicate solution and sulphuric acid in emulsion medium. Coll. Surf. A PhysicoChem. Eng. Asp. 2001, 190, 153-165. [CrossRef]

77. Jesionowski, T.; Krysztafkiewicz, A. Preparation of the hydrophilic/hydrophobic silica particles. Coll. Surf. A PhysicoChem. Eng. Asp. 2002, 207, 49-58. [CrossRef]

78. Liese, A.; Hilterhaus, L. Evaluation of immobilized enzymes for industrial applications. Chem. Soc. Rev. 2013, 42, 6236-6249. [CrossRef]

79. Macario, A.; Verri, F.; Diaz, U.; Corma, A.; Giordano, G. Pure silica nanoparticles for liposome/lipase system encapsulation: Application in biodiesel production. Catal. Today 2013, 204, 148-155. [CrossRef]

80. Babaki, M.; Yousefi, M.; Habibi, Z.; Mohammadi, M.; Yousefi, P.; Mohammadi, J.; Brask, J. Enzymatic production of biodiesel using lipases immobilized on silica nanoparticles as highly reusable biocatalysts: Effect of water, t-butanol and blue silica gel contents. Renew. Energy 2016, 91, 196-206. [CrossRef]

81. Cipolatti, E.P.; Silva, M.J.A.; Klein, M.; Feddern, V.; Feltes, M.M.C.; Oliveira, J.V.; Ninow, J.L.; de Oliveira, D. Current status and trends in enzymatic nanoimmobilization. J. Mol. Catal. B Enzymatic 2014, 99, 56-67. [CrossRef]

82. Dumri, K.; Hung Anh, D. Immobilization of Lipase on Silver Nanoparticles via Adhesive Polydopamine for Biodiesel Production. Enzyme 2014, 389739. [CrossRef] [PubMed]

83. Chen, Y.Z.; Ching, C.B.; Xu, R. Lipase immobilization on modified zirconia nanoparticles: Studies on the effects of modifiers. Process BioChem. 2009, 44, 1245-1251. [CrossRef]

84. Zhi, J.; Wang, Y.; Lu, Y.; Ma, J.; Luo, G. In situ preparation of magnetic chitosan $/ \mathrm{Fe}_{3} \mathrm{O}_{4}$ composite nanoparticles in tiny pools of water-in-oil microemulsion. React. Funct. Polym. 2006, 66, 1552-1558. [CrossRef]

85. Ghazanfri, M.; Kashefi, M.; Shams, S.; Jaafari, M. Perspective of $\mathrm{Fe}_{3} \mathrm{O}_{4}$ nanoparticles role in biomedical applications. Biochem. Res. Int. 2016, 2016, 7840161.

86. Krajewska, B. Application of chitin- and chitosan-based materials for enzyme immobilizations: A review. Enzyme Microb. Technol. 2004, 35, 126-139. [CrossRef] 
87. Ghadi, A.; Tabandeh, F.; Mahjoub, S.; Mohsenifar, A.; Roshan, F.T.; Alavije, R.S. Fabrication and characterization of core-shell magnetic chitosan nanoparticles as a novel carrier for immobilization of Burkholderia cepacia Lipase. J. Oleo Sci. 2015, 64, 423-430. [CrossRef]

88. Xie, W.; Wang, J. Immobilized lipase on magnetic chitosan microspheres for transesterification of soybean oil. Biomass Bioenerg. 2012, 36, 373-380. [CrossRef]

89. Chen, Y.Z.; Yang, C.T.; Ching, C.B.; Xu, R. Immobilization of Lipases on Hydrophobilized Zirconia Nanoparticles: Highly Enantioselective and Reusable Biocatalysts. Langmuir 2008, 24, 8877-8884.

90. Li, X.-S.; Zhu, G.-T.; Luo, Y.-B.; Yuan, B.-F.; Feng, Y.-Q. Synthesis and applications of functionalized magnetic materials in sample preparation. TrAC Trends Anal. Chem. 2013, 45, 233-247. [CrossRef]

91. Vaghari, H.; Jafarizadeh-Malmiri, H.; Mohammadlou, M.; Berenjian, A.; Anarjan, N.; Jafari, N.; Nasiri, S. Application of magnetic nanoparticles in smart enzyme immobilization. Biotechnol. Lett. 2016, 38, 223-233. [CrossRef] [PubMed]

92. Xie, W.; Zang, X. Immobilized lipase on core-shell structured Fe3O4-MCM-41 nanocomposites as a magnetically recyclable biocatalyst for interesterification of soybean oil and lard. Food Chem. 2016, 194, 1283-1292. [CrossRef]

93. Rosenholm, J.M.; Zhang, J.; Sun, W.; Gu, H. Large-pore mesoporous silica-coated magnetite core-shell nanocomposites and their relevance for biomedical applications. Microporous Mesoporous Mater. 2011, 145, 14-20. [CrossRef]

94. López, C.; Cruz-Izquierdo, Á.; Picó, E.A.; García-Bárcena, T.; Villarroel, N.; Llama, M.J.; Serra, J.L. Magnetic biocatalysts and their uses to obtain biodiesel and biosurfactants. Front. Chem. 2014, 2, 1-11.

95. Jambulingam, R.; Shalma, M.; Shankar, V. Biodiesel production using lipase immobilised functionalized magnetic nanocatalyst from oleaginous fungal lipid. J. Clean. Product. 2019, 215, 245-258. [CrossRef]

96. Shim, M.; Shi Kam, N.W.; Chen, R.J.; Li, Y.; Dai, H. Functionalization of Carbon Nanotubes for Biocompatibility and biomolecular recognition. Nano Lett. 2002, 2, 285-288. [CrossRef]

97. Szelwicka, A.; Boncel, S.; Jurczyk, S.; Chrobok, A. Highly efficient synthesis of alkyl levulinates from $\alpha$-angelica lactone, catalysed with Lewis acidic trifloaluminate ionic liquids supported on carbon nanotubes. ACS Sustain. Chem. Eng. 2019, 7, 5184-5191.

98. Wang, Z.-G.; Wan, L.-S.; Liu, Z.-M.; Huang, X.-J.; Xu, Z.-K. Enzyme immobilization on electrospun polymer nanofibers: An overview. J. Mol. Catal. B Enzymatic 2009, 56, 189-195. [CrossRef]

99. Yang, N.; Chen, X.; Ren, T.; Zhang, P.; Yang, D. Carbon nanotube based biosensors. Sens. Actuators B Chem. 2015, 207, 690-715. [CrossRef]

100. Tan, H.; Feng, W.; Ji, P. Lipase immobilized on magnetic multi-walled carbon nanotubes. Bioresour. Technol. 2012, 115, 172-176. [CrossRef]

101. Zhao, X.; El-Zahab, B.; Brosnahan, R.; Perry, J.; Wang, P. An organic soluble lipase for water-free synthesis of biodiesel. Appl. BioChem. Biotechnol. 2007, 143, 236-243. [CrossRef]

102. Fan, Y.; Wu, G.; Su, F.; Li, K.; Xu, L.; Han, X.; Yan, Y. Lipase oriented-immobilized on dendrimer-coated magnetic multi-walled carbon nanotubes toward catalyzing biodiesel production from waste vegetable oil. Fuel 2016, 178, 172-178. [CrossRef]

103. Sakai, S.; Liu, Y.; Yamaguchi, T.; Watanabe, R.; Kawabe, M.; Kawakami, K. Production of butyl-biodiesel using lipase physically-adsorbed onto electrospun polyacrylonitrile fibers. Bioresour. Technol. 2010, 101, 7344-7349. [CrossRef]

104. Yang, X.Y.; Tian, G.; Jiang, N.; Su, B.L. Immobilization technology: A sustainable solution for biofuel cell design. Energy Environ. Sci. 2012, 5, 5540-5563. [CrossRef]

105. Lu, A.H.; Salabas, E.L.; Schüth, F. Magnetic nanoparticles: Synthesis, protection, functionalization, and application. Angew. Chem. Int. Ed. 2007, 46, 1222-1244. [CrossRef]

106. Sen, T.; Bruce, I.J.; Mercer, T. Fabrication of novel hierarchically ordered porous magnetic nanocomposites for bio-catalysis. Chem. Commun. 2010, 46, 6807-6809. [CrossRef] [PubMed]

(C) 2020 by the authors. Licensee MDPI, Basel, Switzerland. This article is an open access article distributed under the terms and conditions of the Creative Commons Attribution (CC BY) license (http://creativecommons.org/licenses/by/4.0/). 